\title{
Solvent Extraction Studies on Uranium using Amine Based Extractants and Recovery from Low Grade Ore Leach Liquors
}

\author{
Chul-Joo Kim, Jyothi Rajesh Kumar,* Joon-Soo Kim, Jin-Young Lee and Ho-Sung Yoon \\ Extractive Metallurgy Department, Mineral Resources Research Division, Korea Institute of Geoscience and \\ Mineral Resources (KIGAM), 124 Gwahang-no, Yuseong-gu, Daejeon 305-350, Republic of Korea
}

\begin{abstract}
Neste estudo, extratores à base de amina (Alamine 336, Alamine 308, Alamine 304 e Aliquat 336) diluídos em querosene foram usados para extração de urânio e separação de outros elementos associados. Alamine 336 foi o melhor extrator para o processo de extração de urânio de soluções de sulfato quando comparado com outros reagentes à base de amina, Alamine 308, 304 Alamine 336 e Aliquat 336. O comportamento da extração sinérgica foi estudado com aminas como extratantes assim como reagentes sinergistas e organofosforados usados em misturas sinergistas com aminas. Os estudos de extração sinérgica com aminas não foram adequados entre si para melhor eficiência da extração. No entanto, aminas misturadas com extratores organofosforados forneceram comportamento sinérgico positivo, com um coeficiente de 0,567 , calculado a partir de resultados obtidos. A metodologia desenvolvida foi aplicada ao processamento de minério de baixo grau de urânio, e 99,83\% de urânio foi recuperado sem interferências de outros metais.
\end{abstract}

In this study, amine based extractants (Alamine 336, Alamine 308, Alamine 304 and Aliquat 336) diluted in kerosene were used as promising extractants for uranium extraction and separation from other associated elements. Alamine 336 was the best extractant for uranium extraction process from sulfate solutions when compared with other amine based extractants, Alamine 308, Alamine 304 and Aliquat 336. Synergistic extraction behavior was studied with amines as extractants as well as synergists and organophosphorus reagents used as synergist mixed with amines. Synergistic extraction studies with amines were not suitable with each other for better extraction efficiency. However, amines mixed with organophosphorus extractants gave positive synergetic behavior with the highest synergistic coefficient 0.567 calculated from results obtained. The developed methodology was applied to uranium low grade ore processing and $99.83 \%$ of uranium was recovered without the interferences of other metals.

Keywords: uranium, extraction, separation, amine based extractants

\section{Introduction}

Uranium needs are going very fast in new millennium life styles. In this endeavor, researchers are developing new extractive methodologies for uranium recovery from its other associated elements. Uranium is the main source to generate the atomic power as cheap and more quantity of the electricity can be generated to full fill the country demands. For recovery of the precious and rare metals through hydrometallurgical treatments, there is the possibility to develop environmental friendly methods and the vast amount of ongoing research worldwide

*e-mail: rkumarphd@kigam.re.kr, rajeshkumarphd@ rediffmail.com underline the enormity of interest in hydrometallurgy. The hydrometallurgical operations involve many techniques, one of the main and important of them was solvent extraction processing. The technique of solvent extraction (also called liquid-liquid extraction) has played most important role in analytical, separation science as well as environmental sciences and has been used since long time (since 1842). For the extraction and separation of metals from various sources, this technique is the very simplest, easily handled and economically cheapest technique when compared with other analytical and separation techniques.

Amides/amines are the main classes of nitrogen based compounds used for uranium extraction and separation technology. A great number of amides ${ }^{1-6}$ and amines ${ }^{7-12}$ 
was used for the uranium extraction from various sources. Extraction yield of uranium(VI) is higher than that of plutonium(IV) using dioctylethylhexanamide (DOEHA) and diisobutylethylhexanamide (DIBEHA) as extractants. ${ }^{2}$ The dependence of the distribution ratio on the concentration of nitric acid shows that $N, N^{\prime}$-dimethyl- $N, N^{\prime}$-dibutylmalonamide (DMDBMA) has ability to extract uranyl(VI) ions, while the extracting capacity for lanthanide(III) ions is not enough for the application in practice. ${ }^{4}$ The distribution ratios for the extraction of uranium and thorium show second- and third-order dependences, respectively, on the extractant concentration for both the $N$-alkyl and $N, N$-dialkyl amides. ${ }^{5}$ The results of extraction study suggested the formation of the 1:2:1 uranyl(II) ion, nitrate ion and $N, N, N, N$-tetrabutylsuccinylamide complex as extracted species. ${ }^{6}$ Extraction of uranium and separation of thorium/fission products from hydrochloric acid solutions using tri(iso-octyl)amine as extractant were investigated. ${ }^{7}$ The extraction of uranium(IV) from aqueous sulfuric acid media by tri-octylamine (TOA) in benzene was studied as a function of various experimental parameters. ${ }^{8}$ The recovery of uranium from acid heap leach liquor using tertiary amines (tri-n-octylamine) chosen as extractants because of their high selectivity and efficiency was investigated. ${ }^{9}$ The distribution of uranium(VI) between an acidic sulfate solution of ionic strength 1.0 and non-aqueous tri-n-octylammonium sulfate solutions of practical significance in the processing of uranium ores was reported. ${ }^{10}$ Separation of technetium(VII) from uranium(VI) was studied through experiments on the coprecipitation of technetium(VII) (with precipitation of ammonium diuranate). ${ }^{11}$ Extraction behavior of uranium(VI) from nitric acid medium was investigated using organophosphorous extractant, tri(butoxyethyl) phosphate in n-paraffin at room temperature $27 \pm 1^{\circ} \mathrm{C}$. ${ }^{13}$ The extraction behavior of new bi-functional ligands containing sulfoxide and amide groups toward the uranium(VI) ion from nitric acid was studied. ${ }^{14,15}$ Three structural isomers of di-amides were synthesized and investigated on extractability toward uranium(VI). ${ }^{16}$ Back extraction studies revealed that among all common strippants used, $0.5 \mathrm{~mol} \mathrm{~L}^{-1}$ solution of $\left(\mathrm{NH}_{4}\right)_{2} \mathrm{CO}_{3}$ was the most suitable. ${ }^{17}$ $\mathrm{N}, \mathrm{N}$-dialkyl aliphatic amides with varying alkyl groups were compared with organophosphorous extractants, tri- $n$-butyl phosphate (TBP) for third phase formation behavior during the extraction of uranium(VI) from nitric acid medium. ${ }^{18}$ In $\mathrm{UO}_{2}\left(\mathrm{NO}_{3}\right)_{2}$ extraction with quaternary ammonium nitrate and dialkylphosphinic acid solutions in toluene, the compounds $\left(\mathrm{R}_{4} \mathrm{~N}\right)_{2} \mathrm{UO}_{2}\left(\mathrm{NO}_{3}\right)_{4}$ and $\mathrm{UO}_{2} \mathrm{~A}_{2}$ are formed in the organic phase, respectively. ${ }^{19}$ Alamine 336 used as extractant for uranium extraction from sulfate solutions was reported. ${ }^{20-22}$ Our recent review work concluded that nitrogen based extractants such as amines are good class of organic complexing extractants for uranium extraction and separation from its leach solutions. ${ }^{23}$

A very limited number of uranium deposits was identified in Korea and the ores had the low grade uranium values. Solvent extraction is the most convenient analytical technique and easily handles bench scale to pilot plant operations. The aim of the present study is to establish the optimum conditions for uranium recovery from Korean domestic ore acid leach liquors without other impurities. Amine based extractants are proved as novel extractants for uranium extraction and separation from other associated elements. Separation of uranium from other associated elements is desired in view of its increasing demand in nuclear energy program. In this endeavor, it is described a simple procedure for the separation of uranium by its extraction. The leach liquor contains uranium with other elements such as iron, zinc, nickel, aluminum and manganese. Extraction methodologies were developed in synthetic solutions and later it was applied to uranium low grade ore processing by solvent extraction technique.

\section{Experimental}

\section{Apparatus}

Analysis of uranium(VI)/other elements content in aqueous solutions was performed using inductively coupled plasma optimal emission spectrometer (ICP-OES) Perkin Elmer Model Optima 2000 Dr. Operating conditions of ICP-OES for uranium and other associated metal analysis is presented in Table 1.

\section{Reagents}

Stock solution of uranyl acetate $\left(\mathrm{UO}_{2}\left(\mathrm{C}_{2} \mathrm{H}_{3} \mathrm{O}_{2}\right)_{2} \cdot 2 \mathrm{H}_{2} \mathrm{O}\right)$ (Poly Sciences, Inc., Warrington, PA, USA) was prepared in distilled water with addition of concentrated sulfuric acid to prevent hydrolysis of metal ions. The metal solutions used in the solvent extraction studies were prepared from the stock solution. The commercial grade amine based extractants Alamine 336, Alamine 308, Alamine 304 and Aliquat 336 (Cognis Corporation, USA) were used as received without purification. Organophosphorus reagents like tri-butyl-phosphate (TBP) was supplied by Kanto Chemicals Co. Inc. (Japan), di(2-ethylhexyl) phosphoric acid (D2EHPA) and 2-ethylhexyl phosphonic acid mono-2-ethylhexyl ester (PC 88A) by Daihachi Chemicals (Japan), Cyanex 272 and Cyanex 302 by Cytec Korea Inc. (Korea). In the present study, kerosene supplied by Junsei Chemicals Co. Ltd. (Japan) was used as diluent (boiling 
Table 1. ICP-OES parameters and operating conditions for metals ${ }^{24}$

\begin{tabular}{lc}
\hline Parameter & Range \\
\hline Forward power & $800-1200$ \\
Sample gas flow / $\left(\mathrm{L} \mathrm{min}^{-1}\right)$ & $0.20-0.90$ \\
Plasma gas flow / $\left(\mathrm{L} \mathrm{min}^{-1}\right)$ & $10.00-13.00$ \\
Aux. gas flow / $\left(\mathrm{L} \mathrm{min}^{-1}\right)$ & $0.50-1.00$ \\
Pump speed / \% & $5.0-50.0$ \\
Torch height / mm & $3.0-15.0$ \\
Torch mono Posn / mm & -3.0 to 3.0 \\
Torch poly Posn $(9 \mathrm{~mm})$ & -3.0 to 3.0 \\
\hline Metal ion & Wavelength $\left(\lambda_{\max }\right) / \mathrm{nm}$ \\
\hline Uranium & 385.958 \\
Iron & 238.204 \\
Zinc & 202.548 \\
Nickel & 341.476 \\
Aluminum & 396.153 \\
Manganese & 257.610 \\
\hline
\end{tabular}

point of $180-270{ }^{\circ} \mathrm{C}$ and density of 0.80 ). All other reagents used were analytical reagent grade.

\section{Analytical (solvent extraction) procedure}

Distribution ratio of the metal was determined by shaking equal volumes $(25 \mathrm{~mL})$ of aqueous and organic phases for $30 \mathrm{~min}$ in a glass stoppered vial using a mechanical shaker at $25 \pm 0.5^{\circ} \mathrm{C}$. Preliminary experiments showed that the extraction equilibrium was attained within 30 min for uranium with all four amine based extractants from sulfate solutions. The organic and aqueous solutions were then allowed to settle, the phases were separated, and uranium in the aqueous phases was determined by ICP-OES. The concentration of metal ion in the organic phase was then obtained by mass balance. The distribution ratio $\left(D_{\mathrm{e}}\right)$ was defined as the ratio of the concentration of metal ion in organic phase to that in the aqueous phase $\left(D_{\mathrm{e}}=\right.$ metal in organic phase / metal in aqueous phase). The back extraction of the metal from loaded organic phase calculated by distribution ratio, $D_{\mathrm{s}}$ was defined as the ratio of the metal concentration in aqueous phase divide by loaded organic phase. Experimental data of distribution ratios of aqueous phase to organic phase metal transfer presented general agreement within $\pm 5 \%$.

\section{Results and Discussions}

Time effect

The present extraction process developed by first experiment conducted on time effect indicates that $10 \mathrm{~min}$ time is more than enough to reach the extraction equilibrium with all extractants Alamine 336, Alamine 308, Alamine 304 and Aliquat 336 (experimental conditions: $0.1 \mathrm{~mol} \mathrm{~L}^{-1}$ acid, $1 \mathrm{mmol} \mathrm{L}^{-1}$ metal, $0.005 \mathrm{~mol} \mathrm{~L}^{-1}$ extractant). The experimental results demonstrated that with Alamine 336 extractant, the percentage extraction increased from 52 to $55 \%$ by the time varying from 1 to $120 \mathrm{~min}$, similarly in case of Alamine 308 extractant system from 35 to $39 \%$, Alamine 304 extractant system from 7 to $10 \%$ and Aliquat 336 system from 38 to $41 \%$ extraction of the metal concentration were observed. The equilibrium time was optimized as $30 \mathrm{~min}$ for uranium extraction as well as back extraction (stripping) process in the entire experiments. In the present investigations for uranium extraction and other element separations using amine based extractants, the following experimental conditions are constant for the all experiments: time of $30 \mathrm{~min}$, temperature of $25^{\circ} \mathrm{C}$ and aqueous:organic ratio (A:O ratio) of 1:1 that means unit phase ratio.

\section{Acid effect}

The first step of the solvent extraction process development is to know the optimum acidic condition or $\mathrm{pH}$ condition to quantitatively extract the targeted metal. In this present scientific investigations on $1.0 \mathrm{mmol} \mathrm{L}^{-1}$ uranium extraction process, the experiment related to acid effect was carried out in the range of 0.005 to $5.0 \mathrm{~mol} \mathrm{~L}^{-1}$ sulfuric acid at $25{ }^{\circ} \mathrm{C}, \mathrm{A}: \mathrm{O}$ ratio of $1: 1$ and time of $30 \mathrm{~min}$. The acid effect results showed that (Figure 1) Alamine 336 and Alamine 308 influence on the percentage extraction increased with the increase of the acidity up to $0.5 \mathrm{~mol} \mathrm{~L}^{-1}$ whereas, at higher acidity range like 1.0 to $5.0 \mathrm{~mol} \mathrm{~L}^{-1}$ it was reverse (decreased). On the other hand, in case of Alamine 304 as extractant, at lower acidic conditions such as 0.005 and $0.01 \mathrm{~mol} \mathrm{~L}^{-1}$, the metal precipitated. Above $0.1 \mathrm{~mol} \mathrm{~L}^{-1}$ to higher acidity range,

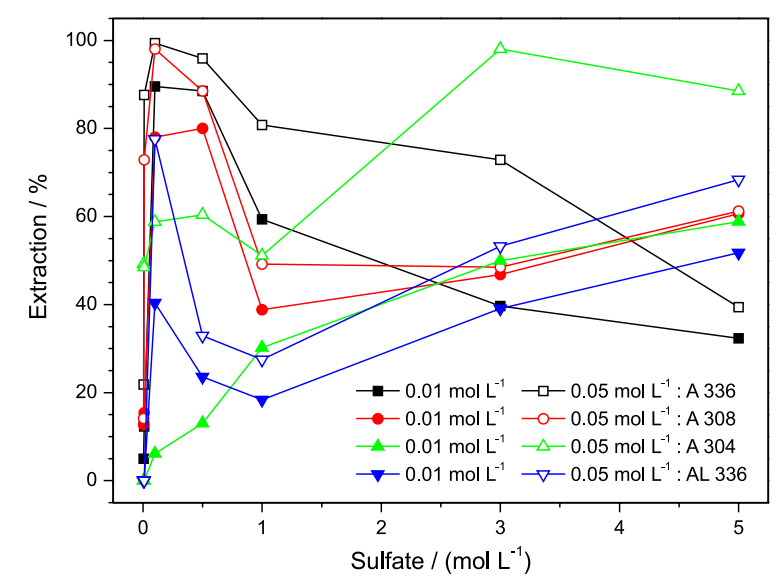

Figure 1. Effect of sulfuric acid on uranium extraction with amine based extractants. A 336: Alamine 336, A 308: Alamine 308, A 304: Alamine 304 and AL 336: Aliquat 336. 
the percentage of extraction increased with the increase of the acid concentration up to $5.0 \mathrm{~mol} \mathrm{~L}^{-1}$. Aliquat 336 was not favorable at lower acidic condition because the metal precipitated; at $0.1 \mathrm{~mol} \mathrm{~L}^{-1}$, it was able to extract the metal up to ca. $78 \%$ with $0.05 \mathrm{~mol} \mathrm{~L}^{-1}$ extractant concentration.

\section{Extractant effect}

To optimize the extractant concentration for $1.0 \mathrm{mmol} \mathrm{L}^{-1}$ uranium extraction, the extractant effect was studied in the range of 0.005 to $0.5 \mathrm{~mol} \mathrm{~L}^{-1}$ amine based extractants (Alamine 336, Alamine 308, Alamine 304 and Aliquat 336) diluted in kerosene at 0.1 and $1.0 \mathrm{~mol} \mathrm{~L}^{-1}$ sulfuric acid solutions. The results clearly demonstrated that the percentage extraction increased with the increase of the extractant concentration. The lower acidic condition like $0.1 \mathrm{~mol} \mathrm{~L}^{-1}$ favored the extraction when compared with $1.0 \mathrm{~mol} \mathrm{~L}^{-1}$ acidic condition (Figure 2). The extraction efficiency order for amine extractants was as follows:

Alamine 336 > Alamine 308 > Alamine 304 > Aliquat 336.

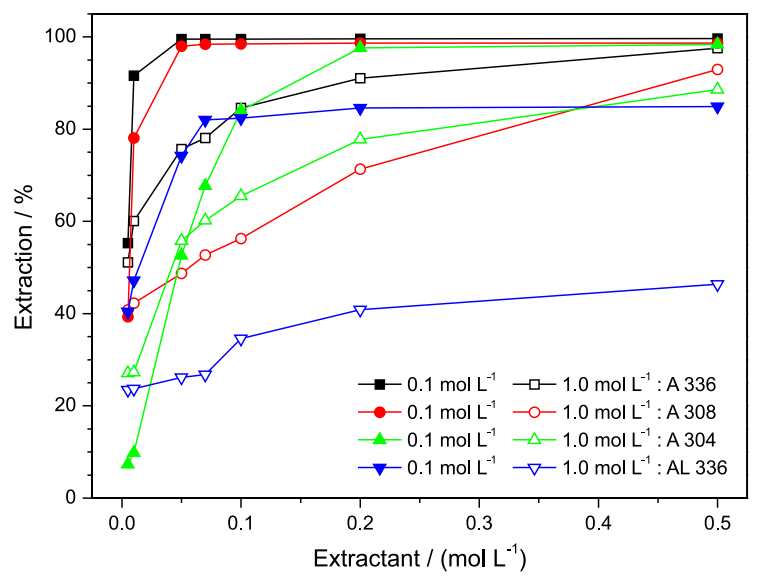

Figure 2. Effect of extractant concentration on uranium extraction with amine based extractants. A 336: Alamine 336, A 308: Alamine 308, A 304: Alamine 304 and AL 336: Aliquat 336.

\section{Metal ion effect}

Metal ion influence on the extraction process was tested by varying the metal ion (uranium) concentration 0.5 to $2.0 \mathrm{~mol} \mathrm{~L}^{-1}$ at $0.1 \mathrm{~mol} \mathrm{~L}^{-1}$ sulfate concentration with $0.01 \mathrm{~mol} \mathrm{~L}^{-1}$ extractant concentration (Alamine 336 or Alamine 308, Alamine 304 or Aliquat 336). Three extractants showed that the distribution ratio decreased by the increase of the metal ion concentration (Figure 3), whereas in case of Alamine 304 as extractant, the distribution ratio slightly increased and almost constant throughout the metal range $\left(D_{e}=0.05 \pm 0.02\right)$. The extraction efficiency order for amine extractants was as follows:

Alamine $336>$ Alamine $308>$ Aliquat 336 > Alamine 308 .
Amine based extractants follows two types of aqueous mechanisms:

Protonation: $\left[\mathrm{R}_{3} \mathrm{~N}\right]_{\text {org }}+[\mathrm{HA}]_{\mathrm{aq}} \rightarrow\left[\mathrm{R}_{3} \mathrm{NH}^{+} \mathrm{A}^{-}\right]_{\text {org }}$, Exchange: $\left[\mathrm{R}_{3} \mathrm{NH}^{+} \mathrm{A}^{-}\right]_{\text {org }}+\left[\mathrm{B}^{-}\right]_{\mathrm{aq}} \rightarrow\left[\mathrm{R}_{3} \mathrm{NH}^{+} \mathrm{B}^{-}\right]_{\mathrm{org}}+\left[\mathrm{A}^{-}\right]_{\mathrm{aq}}$

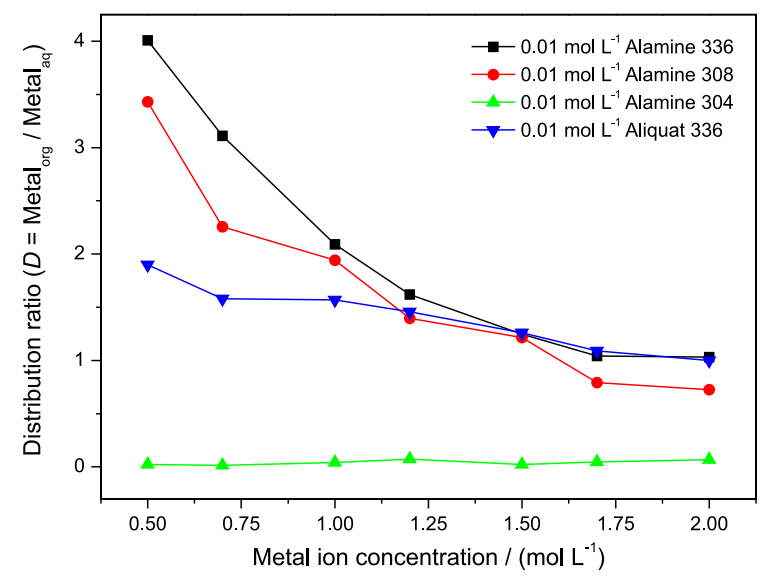

Figure 3. Effect of metal ion (uranium) concentration with amine based extractants.

In the present study, a wide range of acid concentration was studied. In lower acidic concentrations, from 0.005 to $0.1 \mathrm{~mol} \mathrm{~L}^{-1}$ sulfate concentration, the amine based extractants follow the protonation mechanism. Thereafter, the ion-exchange mechanism is followed up to $3.0 \mathrm{~mol} \mathrm{~L}^{-1}$ sulfate concentration for all amine based extractants except for Alamine 308.

\section{Phase ratio effect}

Phase ratio (A:O ratio) was studied using $0.005 \mathrm{~mol} \mathrm{~L}^{-1}$ extractant (Alamine 336 or Alamine 308 or Alamine 304 or Aliquat 336) concentration at $0.1 \mathrm{~mol} \mathrm{~L}^{-1}$ sulfate concentration for $1.0 \mathrm{mmol} \mathrm{L}^{-1}$ uranium extraction process. The experimental results are presented in Figure 4 and

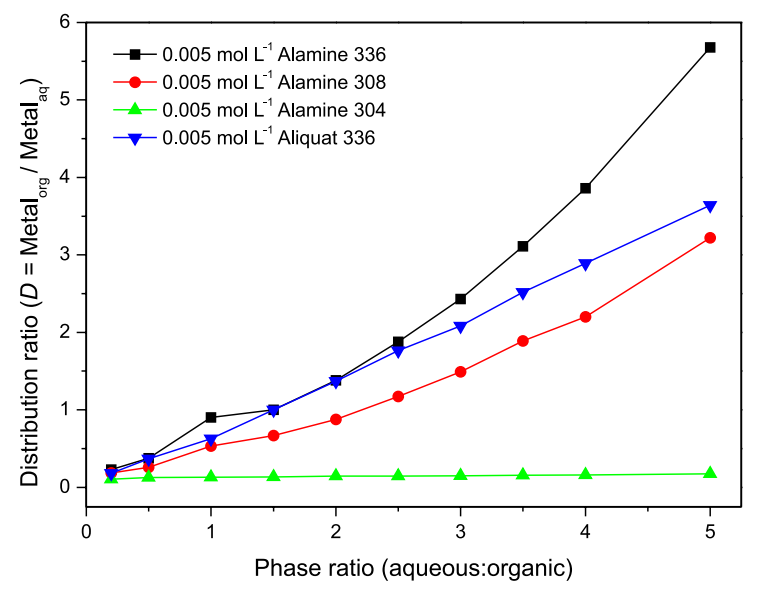

Figure 4. Effect of phase ratio on uranium extraction from sulfate solutions with amine based extractants. 
indicated that ca. 18.7 to $85 \%$ uranium was extracted with Alamine 336, ca. 16.0 to $76.4 \%$ for Alamine 308, 9.6 to $14.9 \%$ for Alamine 304 and 15.3 to $78.6 \%$ for Aliquat 336 with the increase of the phase ratio from 0.2 to $5.0(\mathrm{~A}: \mathrm{O}$ ratio). The extraction efficiency order for amine extractants was as follows:

Alamine 336 > Aliquat 336 > Alamine 308 > Alamine 304 .

\section{Salt effect}

Various metal salts, $\mathrm{LiCl}, \mathrm{LiNO}_{3}, \mathrm{Li}_{2} \mathrm{SO}_{4}, \mathrm{NaCl}, \mathrm{NaNO}_{3}$, $\mathrm{Na}_{2} \mathrm{SO}_{4}, \mathrm{KCl}, \mathrm{KNO}_{3}$ and $\mathrm{K}_{2} \mathrm{CO}_{3}$, were tested for uranium extraction process to improve the extraction efficiency. The following experimental conditions were maintained for salt effect study: $1.0 \mathrm{~mol} \mathrm{~L}^{-1}$ salt concentration, $1.0 \mathrm{mmol} \mathrm{L}{ }^{-1}$ metal concentration, 0.1 and $1.0 \mathrm{~mol} \mathrm{~L}^{-1}$ sulfate concentrations and 0.001 and $0.005 \mathrm{~mol} \mathrm{~L}^{-1}$ extractant (Alamine 336 or Alamine 308, Alamine 304 or Aliquat 336) concentrations. The experimental results are presented in Table 2 . The results clearly demonstrated that four amine based extractants with good extraction ability with different metal salts. The extraction efficiency order for amine extractants was as follows:

(i) Alamine 336: $\mathrm{Na}_{2} \mathrm{SO}_{4}>\mathrm{Li}_{2} \mathrm{SO}_{4}>\mathrm{K}_{2} \mathrm{CO}_{3}>\mathrm{NaNO}_{3}>$ $\mathrm{Na}_{2} \mathrm{CO}_{3}>\mathrm{KCl}>\mathrm{KNO}_{3}>\mathrm{LiCl}>\mathrm{LiNO}_{3}>\mathrm{NaCl}$;

(ii) Alamine 308: $\mathrm{K}_{2} \mathrm{CO}_{3}>\mathrm{NaCl}>\mathrm{Li}_{2} \mathrm{SO}_{4}>\mathrm{NaNO}_{3}>\mathrm{LiCl}>$ $\mathrm{Na}_{2} \mathrm{CO}_{3}>\mathrm{KCl}>\mathrm{Na}_{2} \mathrm{SO}_{4}>\mathrm{LiNO}_{3}>\mathrm{KNO}_{3}$;

(iii) Alamine 304: $\mathrm{K}_{2} \mathrm{CO}_{3}>\mathrm{KNO}_{3}>\mathrm{Na}_{2} \mathrm{SO}_{4}>\mathrm{Na}_{2} \mathrm{CO}_{3}>$ $\mathrm{NaNO}_{3}>\mathrm{NaCl}>\mathrm{KCl}>\mathrm{Li}_{2} \mathrm{SO}_{4}>\mathrm{LiCl}>\mathrm{LiNO}_{3}$;

(iv) Aliquat 336: $\mathrm{Li}_{2} \mathrm{SO}_{4}>\mathrm{Na}_{2} \mathrm{SO}_{4}>\mathrm{Na}_{2} \mathrm{CO}_{3}>\mathrm{KCl}>\mathrm{LiCl}>$ $\mathrm{LiNO}_{3}>\mathrm{K}_{2} \mathrm{CO}_{3}>\mathrm{NaNO}_{3}>\mathrm{KNO}_{3}>\mathrm{NaCl}$.

\section{Synergistic studies}

The main objective for the synergistic extraction is to recover the maximum metal using low concentration extractant with synergist. The synergism is measured by synergistic coefficient factor (S.C.). ${ }^{25}$ The S.C. values revealed that the synergistic behavior in the extraction processing is positive if S.C. is higher than 0, negative if S.C. is smaller than 0 and has no effect when S.C. is equal to 0 . On the other hand, the synergistic enhancement factor (S.E.F.) refers to the enhancement of the extraction efficiency when the metal ion is contact with two extractants for the extraction process. In the present study, the uranium extraction efficiency improvement was targeted through mixture of amine based extractants Alamine 336, Alamine 308, Alamine 304 and Aliquat 336. Synergistic experiments were carried out by maintaining constant the following experimental conditions: $1.0 \mathrm{~mol} \mathrm{~L}^{-1} \mathrm{H}_{2} \mathrm{SO}_{4}$, extractant concentration of $1.0 \times 10^{-4} \mathrm{~mol} \mathrm{~L}^{-1}$, synergistic concentration of $0.1 \times 10^{-4}$ to $1.0 \times 10^{-4} \mathrm{~mol} \mathrm{~L}^{-1}$, time of $30 \mathrm{~min}, \mathrm{~A}: \mathrm{O}$ ratio of $1: 1$ for amines as extractants, as well as synergists. Whereas other experiments were conducted using organophosphorus extractants as synergists with amines, and the following conditions were applied: $0.001 \mathrm{~mol} \mathrm{~L}^{-1}$ extractant concentration (amines), 0.001 to $0.01 \mathrm{~mol} \mathrm{~L}^{-1}$ organophosphorus reagents (TBP, D2EHPA, PC 88A, Cyanex 272 and Cyanex 302). The synergistic enhancement factor of the all amine based extractants is presented in Table 3 .

The results are presented in Figure 5 and clearly demonstrated that all systems related to amines gave negative synergistic behavior, whereas organophosphorus reagents showed positive synergistic behavior.

The order of the synergistic behavior with organophosphorus reagents were as follows:

(i) $0.001 \mathrm{~mol} \mathrm{~L}^{-1}$ Alamine 336 or Alamine 308 or Alamine 304 as extractant: Cyanex 272 > PC 88A > D2EHPA > TBP > Cyanex 302;

(ii) Whereas in the case of $0.001 \mathrm{~mol} \mathrm{~L}^{-1}$ Aliquat 336 as extractant: PC 88A > Cyanex 272 > Cyanex $302>$ D2EHPA > TBP;

Table 2. Metal salts effect on uranium extraction from sulfate solutions

\begin{tabular}{|c|c|c|c|c|c|c|c|c|}
\hline \multirow{3}{*}{$\begin{array}{l}\text { Salt, } \\
1.0 \mathrm{~mol} \mathrm{~L}^{-1}\end{array}$} & \multicolumn{8}{|c|}{ Extraction / \% (at $\left.0.1 \mathrm{~mol} \mathrm{~L}^{-1} \mathrm{H}_{2} \mathrm{SO}_{4}\right)$} \\
\hline & \multicolumn{2}{|c|}{ Alamine 336} & \multicolumn{2}{|c|}{ Alamine 308} & \multicolumn{2}{|c|}{ Alamine 304} & \multicolumn{2}{|c|}{ Aliquat 336} \\
\hline & $0.001 \mathrm{~mol} \mathrm{~L}^{-1}$ & $0.005 \mathrm{~mol} \mathrm{~L}^{-1}$ & $0.001 \mathrm{~mol} \mathrm{~L}^{-1}$ & $0.005 \mathrm{~mol} \mathrm{~L}^{-1}$ & $0.001 \mathrm{~mol} \mathrm{~L}^{-1}$ & $0.005 \mathrm{~mol} \mathrm{~L}^{-1}$ & $0.001 \mathrm{~mol} \mathrm{~L}^{-1}$ & $0.005 \mathrm{~mol} \mathrm{~L}$ \\
\hline $\mathrm{LiCl}$ & 17.06 & 31.4 & $>1$ & 33.3 & $>1$ & 29.2 & $>2$ & 33.9 \\
\hline $\mathrm{LiNO}_{3}$ & 22.18 & 29.1 & ca. 8.0 & 31.0 & $>1$ & 28.6 & $>1$ & 32.4 \\
\hline $\mathrm{Li}_{2} \mathrm{SO}_{4}$ & 20.89 & 39.1 & $>2$ & 35.6 & $>1$ & 32.6 & $>2$ & 65.9 \\
\hline $\mathrm{Na}_{2} \mathrm{CO}_{3}$ & 14.17 & 32.8 & $>3$ & 32.8 & $>1$ & 39.3 & $>2$ & 41.7 \\
\hline $\mathrm{NaCl}$ & 16.18 & 29.0 & $>1$ & 37.0 & $>1$ & 35.2 & $>1$ & 30.6 \\
\hline $\mathrm{NaNO}_{3}$ & 16.88 & 35.1 & $>1$ & 35.4 & $>1$ & 36.4 & $>1$ & 31.6 \\
\hline $\mathrm{Na}_{2} \mathrm{SO}_{4}$ & 17.44 & 40.0 & $>1$ & 31.0 & $>1$ & 39.8 & $>1$ & 55.7 \\
\hline $\mathrm{KCl}$ & 16.86 & 32.5 & $>1$ & 31.2 & $>1$ & 33.6 & $>1$ & 39.8 \\
\hline $\mathrm{KNO}_{3}$ & 18.49 & 32.3 & $>1$ & 28.4 & $>1$ & 40.4 & $>1$ & 31.3 \\
\hline $\mathrm{K}_{2} \mathrm{CO}_{3}$ & 09.49 & 38.0 & $>1$ & 40.1 & $>1$ & 58.1 & $>2$ & 32.7 \\
\hline
\end{tabular}


Table 3. Synergistic enhancement factor for uranium extraction with amine based extractants

\begin{tabular}{|c|c|c|c|c|c|c|c|}
\hline $\begin{array}{l}\text { Concentration of } \\
\text { the extractant / } \\
\left(\mathrm{mol} \mathrm{L}^{-1}\right)\end{array}$ & $\begin{array}{l}\text { Distribution ratio } \\
\text { of the extractant } \\
\qquad\left(D_{\mathrm{A}}\right)\end{array}$ & $\begin{array}{c}\text { Concentration } \\
\text { of the synergist / } \\
\left(\mathrm{mol} \mathrm{L}^{-1}\right)\end{array}$ & $\begin{array}{l}\text { Distribution ratio } \\
\text { of the synergist } \\
\qquad\left(D_{\mathrm{B}}\right)\end{array}$ & $\begin{array}{c}\text { Distribution ratio } \\
\text { of the mixture } \\
\text { of extractant and } \\
\text { synergist } \\
\left(D_{\mathrm{A}+\mathrm{B}}\right)\end{array}$ & $\begin{array}{c}\text { Sum of the } \\
\text { distribution ratio } \\
\text { of extractant and } \\
\text { synergist } \\
\left(D_{\mathrm{A}}+D_{\mathrm{B}}\right)\end{array}$ & $\begin{array}{c}\Delta D=\left(D_{\mathrm{A}+\mathrm{B}}\right)- \\
\left(D_{\mathrm{A}}+D_{\mathrm{B}}\right)\end{array}$ & $\begin{array}{c}\text { Synergistic } \\
\text { enhancement } \\
\text { factor }(\text { S.E.F. })= \\
D_{\mathrm{A}+\mathrm{B}} /\left(D_{\mathrm{A}}+D_{\mathrm{B}}\right)\end{array}$ \\
\hline \multicolumn{8}{|c|}{ Alamine 336} \\
\hline $1.0 \times 10^{-4}$ & 0.066 & $0.1 \times 10^{-3}$ A 308 & 0.0839 & 0.05 & 0.1499 & -0.099 & 0.3335 \\
\hline $1.0 \times 10^{-4}$ & 0.066 & $0.5 \times 10^{-3}$ A 308 & 0.090 & 0.059 & 0.156 & -0.097 & 0.3782 \\
\hline $1.0 \times 10^{-4}$ & 0.066 & $1.0 \times 10^{-3}$ A 308 & 0.138 & 0.08 & 0.204 & -0.124 & 0.3921 \\
\hline $1.0 \times 10^{-4}$ & 0.066 & $0.1 \times 10^{-3}$ A 304 & 0.0657 & 0.106 & 0.1317 & -0.0257 & 0.8048 \\
\hline $1.0 \times 10^{-4}$ & 0.066 & $0.5 \times 10^{-3}$ A 304 & 0.097 & 0.127 & 0.163 & -0.036 & 0.7791 \\
\hline $1.0 \times 10^{-4}$ & 0.066 & $1.0 \times 10^{-3}$ A 304 & 0.103 & 0.142 & 0.169 & -0.027 & 0.8402 \\
\hline $1.0 \times 10^{-4}$ & 0.066 & $0.1 \times 10^{-3}$ AL 336 & 0.066 & 0.053 & 0.132 & -0.079 & 0.4015 \\
\hline $1.0 \times 10^{-4}$ & 0.066 & $0.5 \times 10^{-3}$ AL 336 & 0.116 & 0.1036 & 0.182 & -0.0784 & 0.5692 \\
\hline $1.0 \times 10^{-4}$ & 0.066 & $1.0 \times 10^{-3}$ AL 336 & 0.126 & 0.126 & 0.192 & -0.066 & 0.6562 \\
\hline 0.001 & 0.132 & 0.001 ТВР & 0.000 & 0.128 & 0.132 & -0.004 & 0.969 \\
\hline 0.001 & 0.132 & 0.005 TBP & 0.000 & 0.091 & 0.132 & -0.041 & 0.689 \\
\hline 0.001 & 0.132 & $0.01 \mathrm{TBP}$ & 0.000 & 0.067 & 0.1 .32 & -0.065 & 0.507 \\
\hline 0.001 & 0.132 & 0.001 D2EHPA & 0.07 & 0.154 & 0.202 & -0.048 & 0.762 \\
\hline 0.001 & 0.132 & 0.005 D2EHPA & 0.428 & 0.636 & 0.560 & 0.076 & 1.135 \\
\hline 0.001 & 0.132 & $0.01 \mathrm{D} 2 \mathrm{EHPA}$ & 1.495 & 1.944 & 1.627 & 0.317 & 1.194 \\
\hline 0.001 & 0.132 & $0.001 \mathrm{PC} 88 \mathrm{~A}$ & 0.000 & 0.035 & 0.132 & -0.097 & 0.265 \\
\hline 0.001 & 0.132 & 0.005 PC $88 \mathrm{~A}$ & 0.513 & 0.625 & 0.645 & -0.020 & 0.968 \\
\hline 0.001 & 0.132 & $0.01 \mathrm{PC} 88 \mathrm{~A}$ & 1.811 & 2.374 & 1.943 & 0.431 & 1.221 \\
\hline 0.001 & 0.132 & 0.001 Cyanex 272 & 0.061 & 0.192 & 0.193 & -0.001 & 0.994 \\
\hline 0.001 & 0.132 & 0.005 Cyanex 272 & 0.536 & 0.636 & 0.668 & -0.032 & 0.952 \\
\hline 0.001 & 0.132 & 0.01 Cyanex 272 & 1.555 & 2.99 & 1.687 & 1.303 & 1.772 \\
\hline 0.001 & 0.132 & 0.001 Cyanex 302 & 0.084 & 0.108 & 0.240 & -0.132 & 0.450 \\
\hline 0.001 & 0.132 & 0.005 Cyanex 302 & 0.091 & 0.086 & 0.223 & -0.137 & 0.385 \\
\hline 0.001 & 0.132 & 0.01 Cyanex 302 & 0.100 & 0.100 & 0.232 & -0.132 & 0.431 \\
\hline \multicolumn{8}{|c|}{ Alamine 308} \\
\hline $1.0 \times 10^{-4}$ & 0.0839 & $0.1 \times 10^{-3}$ A 336 & 0.066 & 0.047 & 0.1499 & -0.1029 & 0.3135 \\
\hline $1.0 \times 10^{-4}$ & 0.0839 & $0.5 \times 10^{-3} \mathrm{~A} 336$ & 0.131 & 0.057 & 0.2249 & -0.1679 & 0.2652 \\
\hline $1.0 \times 10^{-4}$ & 0.0839 & $1.0 \times 10^{-3}$ A 336 & 0.132 & 0.103 & 0.2159 & -0.1129 & 0.4770 \\
\hline $1.0 \times 10^{-4}$ & 0.0839 & $0.1 \times 10^{-3}$ A 304 & 0.0657 & 0.022 & 0.1059 & -0.0839 & 0.2077 \\
\hline $1.0 \times 10^{-4}$ & 0.0839 & $0.5 \times 10^{-3}$ A 304 & 0.097 & 0.053 & 0.1809 & -0.1279 & 0.2929 \\
\hline $1.0 \times 10^{-4}$ & 0.0839 & $1.0 \times 10^{-3}$ A 304 & 0.103 & 0.057 & 0.1869 & -0.1299 & 0.3802 \\
\hline $1.0 \times 10^{-4}$ & 0.0839 & $0.1 \times 10^{-3}$ AL 336 & 0.066 & 0.185 & 0.1499 & 0.0351 & 1.2341 \\
\hline $1.0 \times 10^{-4}$ & 0.0839 & $0.5 \times 10^{-3}$ AL 336 & 0.116 & 0.256 & 0.3399 & -0.0839 & 0.7531 \\
\hline $1.0 \times 10^{-4}$ & 0.0839 & $1.0 \times 10^{-3}$ AL 336 & 0.126 & 0.270 & 0.3539 & -0.0839 & 0.7629 \\
\hline 0.001 & 0.138 & 0.001 TBP & 0.000 & 0.069 & 0.138 & -0.069 & 0.500 \\
\hline 0.001 & 0.138 & 0.005 TBP & 0.000 & 0.058 & 0.138 & -0.080 & 0.420 \\
\hline 0.001 & 0.138 & $0.01 \mathrm{TBP}$ & 0.000 & 0.055 & 0.138 & -0.083 & 0.398 \\
\hline 0.001 & 0.138 & 0.001 D2EHPA & 0.070 & 0.141 & 0.208 & -0.067 & 0.677 \\
\hline 0.001 & 0.138 & 0.005 D2EHPA & 0.428 & 0.640 & 0.566 & 0.074 & 1.130 \\
\hline 0.001 & 0.138 & $0.01 \mathrm{D} 2 \mathrm{EHPA}$ & 1.495 & 2.31 & 1.633 & 0.677 & 1.410 \\
\hline 0.001 & 0.138 & $0.001 \mathrm{PC} 88 \mathrm{~A}$ & 0.000 & 0.166 & 0.138 & 0.028 & 1.200 \\
\hline 0.001 & 0.138 & $0.005 \mathrm{PC} 88 \mathrm{~A}$ & 0.513 & 0.727 & 0.651 & 0.076 & 1.110 \\
\hline 0.001 & 0.138 & 0.01 PC 88A & 1.811 & 3.256 & 1.949 & 1.307 & 1.670 \\
\hline 0.001 & 0.138 & 0.001 Cyanex 272 & 0.061 & 0.163 & 0.199 & -0.036 & 0.819 \\
\hline 0.001 & 0.138 & 0.005 Cyanex 272 & 0.536 & 0.548 & 0.674 & -0.126 & 0.813 \\
\hline 0.001 & 0.138 & 0.01 Cyanex 272 & 1.555 & 2.99 & 1.693 & 1.297 & 1.766 \\
\hline 0.001 & 0.138 & 0.001 Cyanex 302 & 0.084 & 0.054 & 0.222 & -0.168 & 0.243 \\
\hline 0.001 & 0.138 & 0.005 Cyanex 302 & 0.091 & 0.049 & 0.229 & -0.180 & 0.213 \\
\hline 0.001 & 0.138 & 0.01 Cyanex 302 & 0.100 & 0.086 & 0.238 & -0.152 & 0.361 \\
\hline
\end{tabular}


Table 3. continuation

\begin{tabular}{|c|c|c|c|c|c|c|c|}
\hline $\begin{array}{l}\text { Concentration of } \\
\text { the extractant / } \\
\left(\mathrm{mol} \mathrm{L}^{-1}\right)\end{array}$ & $\begin{array}{c}\text { Distribution ratio } \\
\text { of the extractant } \\
\left(D_{\mathrm{A}}\right)\end{array}$ & $\begin{array}{c}\text { Concentration } \\
\text { of the synergist / } \\
\left(\mathrm{mol} \mathrm{L}^{-1}\right)\end{array}$ & $\begin{array}{l}\text { Distribution ratio } \\
\text { of the synergist } \\
\left(D_{\mathrm{B}}\right)\end{array}$ & $\begin{array}{c}\text { Distribution ratio } \\
\text { of the mixture } \\
\text { of extractant and } \\
\text { synergist } \\
\left(D_{\mathrm{A}+\mathrm{B}}\right)\end{array}$ & $\begin{array}{c}\text { Sum of the } \\
\text { distribution ratio } \\
\text { of extractant and } \\
\text { synergist } \\
\left(D_{\mathrm{A}}+D_{\mathrm{B}}\right) \\
\end{array}$ & $\begin{array}{c}\Delta D=\left(D_{\mathrm{A}+\mathrm{B}}\right)- \\
\left(D_{\mathrm{A}}+D_{\mathrm{B}}\right)\end{array}$ & $\begin{array}{c}\text { Synergistic } \\
\text { enhancement } \\
\text { factor }(\text { S.E.F. })= \\
D_{\mathrm{A}+\mathrm{B}} /\left(D_{\mathrm{A}}+D_{\mathrm{B}}\right)\end{array}$ \\
\hline \multicolumn{8}{|c|}{ Alamine 304} \\
\hline $1.0 \times 10^{-4}$ & 0.0657 & $0.1 \times 10^{-3}$ A 336 & 0.066 & 0.015 & 0.1317 & -0.1167 & 0.1138 \\
\hline $1.0 \times 10^{-4}$ & 0.0657 & $0.5 \times 10^{-3}$ A 336 & 0.131 & 0.052 & 0.1967 & -0.1447 & 0.2643 \\
\hline $1.0 \times 10^{-4}$ & 0.0657 & $1.0 \times 10^{-3}$ A 336 & 0.132 & 0.0801 & 0.1977 & -0.1176 & 0.4051 \\
\hline $1.0 \times 10^{-4}$ & 0.0657 & $0.1 \times 10^{-3}$ A 308 & 0.0839 & 0.0036 & 0.1496 & -0.1460 & 0.024 \\
\hline $1.0 \times 10^{-4}$ & 0.0657 & $0.5 \times 10^{-3}$ A 308 & 0.09 & 0.0517 & 0.1557 & -0.104 & 0.332 \\
\hline $1.0 \times 10^{-4}$ & 0.0657 & $1.0 \times 10^{-3} \mathrm{~A} 308$ & 0.138 & 0.089 & 0.2037 & -0.1147 & 0.4369 \\
\hline $1.0 \times 10^{-4}$ & 0.0657 & $0.1 \times 10^{-3}$ AL 336 & 0.066 & 0.018 & 0.1317 & -0.1137 & 0.1366 \\
\hline $1.0 \times 10^{-4}$ & 0.0657 & $0.5 \times 10^{-3}$ AL 336 & 0.116 & 0.0402 & 0.1817 & -0.1415 & 0.2212 \\
\hline $1.0 \times 10^{-4}$ & 0.0657 & $1.0 \times 10^{-3}$ AL 336 & 0.126 & 0.142 & 0.1917 & -0.0497 & 0.7407 \\
\hline 0.001 & 0.103 & 0.001 ТВР & 0.000 & 0.069 & 0.103 & -0.034 & 0.669 \\
\hline 0.001 & 0.103 & 0.005 TBP & 0.000 & 0.073 & 0.103 & -0.030 & 0.708 \\
\hline 0.001 & 0.103 & 0.01 ТВР & 0.000 & 0.077 & 0.103 & -0.026 & 0.747 \\
\hline 0.001 & 0.103 & 0.001 D2EHPA & 0.070 & 0.134 & 0.173 & -0.039 & 0.774 \\
\hline 0.001 & 0.103 & 0.005 D2EHPA & 0.428 & 0.489 & 0.531 & -0.042 & 0.920 \\
\hline 0.001 & 0.103 & $0.01 \mathrm{D} 2 \mathrm{EHPA}$ & 1.495 & 1.763 & 1.598 & 0.165 & 1.103 \\
\hline 0.001 & 0.103 & $0.001 \mathrm{PC} 88 \mathrm{~A}$ & 0.000 & 0.114 & 0.103 & 0.011 & 1.100 \\
\hline 0.001 & 0.103 & 0.005 PC $88 \mathrm{~A}$ & 0.513 & 0.617 & 0.616 & 0.001 & 1.000 \\
\hline 0.001 & 0.103 & $0.01 \mathrm{PC} 88 \mathrm{~A}$ & 1.811 & 2.460 & 1.914 & 0.546 & 1.280 \\
\hline 0.001 & 0.103 & 0.001 Cyanex 272 & 0.061 & 0.013 & 0.164 & -0.151 & 0.079 \\
\hline 0.001 & 0.103 & 0.005 Cyanex 272 & 0.536 & 0.328 & 0.639 & -0.311 & 0.513 \\
\hline 0.001 & 0.103 & 0.01 Cyanex 272 & 1.555 & 2.410 & 1.658 & 0.752 & 1.453 \\
\hline 0.001 & 0.103 & 0.001 Cyanex 302 & 0.084 & 0.001 & 0.187 & -0.186 & 0.005 \\
\hline 0.001 & 0.103 & 0.005 Cyanex 302 & 0.091 & 0.0675 & 0.194 & -0.1265 & 0.347 \\
\hline 0.001 & 0.103 & 0.01 Cyanex 302 & 0.100 & 0.110 & 0.203 & -0.093 & 0.541 \\
\hline \multicolumn{8}{|c|}{ Aliquat 336} \\
\hline $1.0 \times 10^{-4}$ & 0.066 & $0.1 \times 10^{-3}$ A 336 & 0.066 & 0.0016 & 0.132 & -0.1304 & 0.0121 \\
\hline $1.0 \times 10^{-4}$ & 0.066 & $0.5 \times 10^{-3} \mathrm{~A} 336$ & 0.131 & 0.0925 & 0.197 & -0.1045 & 0.4695 \\
\hline $1.0 \times 10^{-4}$ & 0.066 & $1.0 \times 10^{-3} \mathrm{~A} 336$ & 0.132 & 0.109 & 0.198 & -0.089 & 0.5505 \\
\hline $1.0 \times 10^{-4}$ & 0.066 & $0.1 \times 10^{-3}$ A 308 & 0.0839 & 0.0159 & 0.1499 & -0.134 & 0.106 \\
\hline $1.0 \times 10^{-4}$ & 0.066 & $0.5 \times 10^{-3}$ A 308 & 0.09 & 0.04 & 0.156 & -0.116 & 0.2564 \\
\hline $1.0 \times 10^{-4}$ & 0.066 & $1.0 \times 10^{-3} \mathrm{~A} 308$ & 0.138 & 0.136 & 0.204 & -0.068 & 0.6667 \\
\hline $1.0 \times 10^{-4}$ & 0.066 & $0.1 \times 10^{-3}$ A 304 & 0.0657 & 0.00 & 1.004 & -1.004 & 0.00 \\
\hline $1.0 \times 10^{-4}$ & 0.066 & $0.5 \times 10^{-3} \mathrm{~A} 304$ & 0.097 & 0.070 & 0.163 & -0.093 & 0.4294 \\
\hline $1.0 \times 10^{-4}$ & 0.066 & $1.0 \times 10^{-3}$ A 304 & 0.103 & 0.094 & 0.169 & -0.075 & 0.5562 \\
\hline 0.001 & 0.126 & $0.001 \mathrm{TBP}$ & 0.000 & 0.159 & 0.126 & 0.033 & 1.261 \\
\hline 0.001 & 0.126 & 0.005 TBP & 0.000 & 0.165 & 0.126 & 0.039 & 1.309 \\
\hline 0.001 & 0.126 & 0.01 ТВР & 0.000 & 0.173 & 0.126 & 0.047 & 1.373 \\
\hline 0.001 & 0.126 & $0.001 \mathrm{D} 2 \mathrm{EHPA}$ & 0.070 & 0.236 & 0.196 & 0.040 & 1.204 \\
\hline 0.001 & 0.126 & 0.005 D2EHPA & 0.428 & 0.635 & 0.554 & 0.081 & 1.146 \\
\hline 0.001 & 0.126 & $0.01 \mathrm{D} 2 \mathrm{EHPA}$ & 1.495 & 2.437 & 1.621 & 0.816 & 1.503 \\
\hline 0.001 & 0.126 & $0.001 \mathrm{PC} 88 \mathrm{~A}$ & 0.000 & 0.196 & 0.126 & 0.070 & 1.555 \\
\hline 0.001 & 0.126 & $0.005 \mathrm{PC} 88 \mathrm{~A}$ & 0.513 & 0.947 & 0.639 & 0.308 & 1.482 \\
\hline 0.001 & 0.126 & 0.01 PC 88A & 1.811 & 7.16 & 1.937 & 5.223 & 3.696 \\
\hline 0.001 & 0.126 & 0.001 Cyanex 272 & 0.061 & 0.467 & 0.187 & 0.280 & 2.497 \\
\hline 0.001 & 0.126 & 0.005 Cyanex 272 & 0.536 & 1.385 & 0.662 & 0.723 & 2.092 \\
\hline 0.001 & 0.126 & 0.01 Cyanex 272 & 1.555 & 5.96 & 1.681 & 4.279 & 3.545 \\
\hline 0.001 & 0.126 & 0.001 Cyanex 302 & 0.084 & 0.282 & 0.210 & 0.072 & 1.342 \\
\hline 0.001 & 0.126 & 0.005 Cyanex 302 & 0.091 & 0.599 & 0.217 & 0.382 & 2.76 \\
\hline 0.001 & 0.126 & 0.01 Cyanex 302 & 0.100 & 0.726 & 0.226 & 0.500 & 3.212 \\
\hline
\end{tabular}

A 336: Alamine 336, A 308: Alamine 308, A 304: Alamine 304 and AL 336: Aliquat 336. 

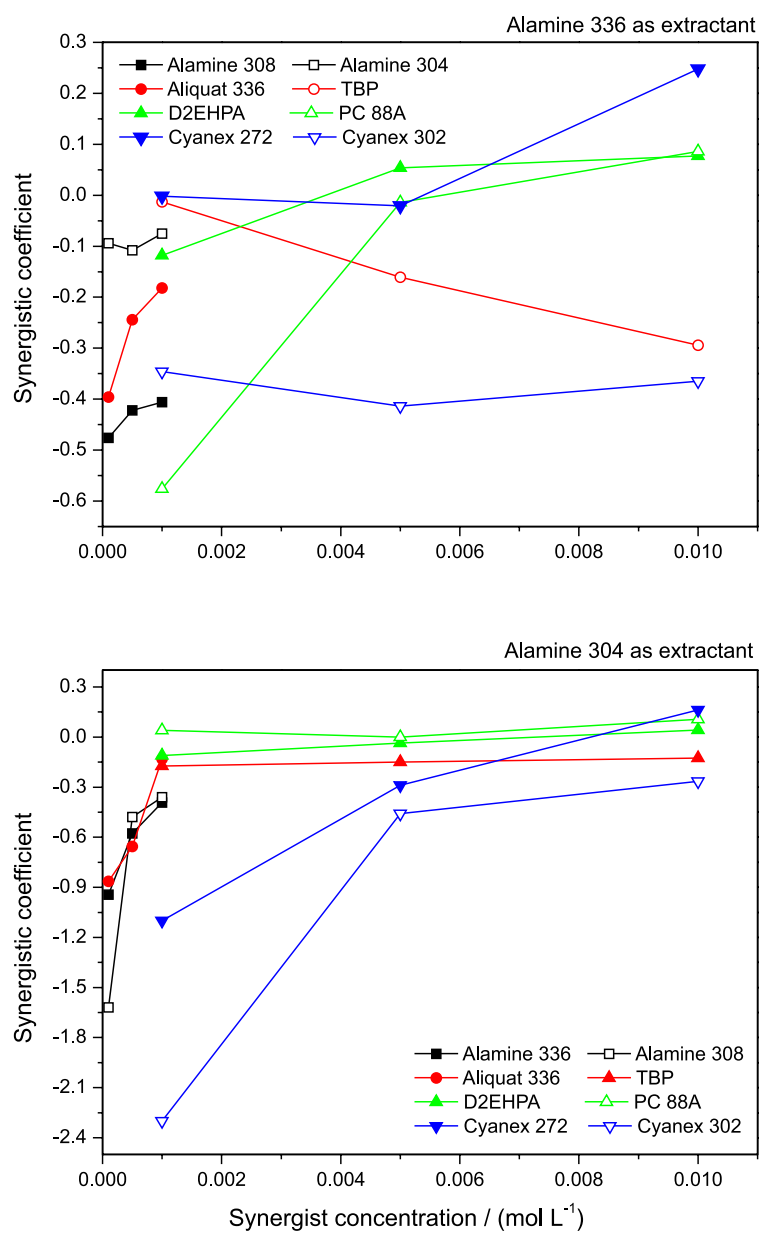

Figure 5. Synergistic extraction studies of the uranium from sulfate solutions.

(iii) Highest synergetic coefficient (S.C.) for Alamine 336 is 0.248 for Alamine 308 is 0.246 and for Alamine 3040.162 with Cyanex 272 as synergist, whereas in case of Aliquat 336 the highest S.C. is 0.567 with PC $88 \mathrm{~A}$ as synergist;

(iv) The order for synergistic behavior is: Aliquat $336>$ Alamine 336 > Alamine 308 > Alamine 304.

The present study concluded that amine based extractants were not suitable for synergistic improvement of the uranium extraction with each other. In contrast, organophosphorus reagents were well suitable for synergism through mixing with amine based extractants for uranium extraction process.

\section{Loading capacity of the extractants}

In commercial solvent extraction process, the extractant maximum loading capacity is the most important result. Aliquot of $100 \mathrm{~mL}$ of $0.01 \mathrm{~mol} \mathrm{~L}^{-1}$ Alamine 336 or Alamine 308 or Alamine 304 or Aliquat 336 was repeatedly contacted for $30 \mathrm{~min}$ with the same volume of aqueous solutions containing $1.0 \mathrm{mmol} \mathrm{L}^{-1}$ of uranium(VI) and $0.1 \mathrm{~mol} \mathrm{~L}^{-1}$ sulfuric acid (Figure 6). After equilibration, the phases were analyzed for metal content. The amount of metal
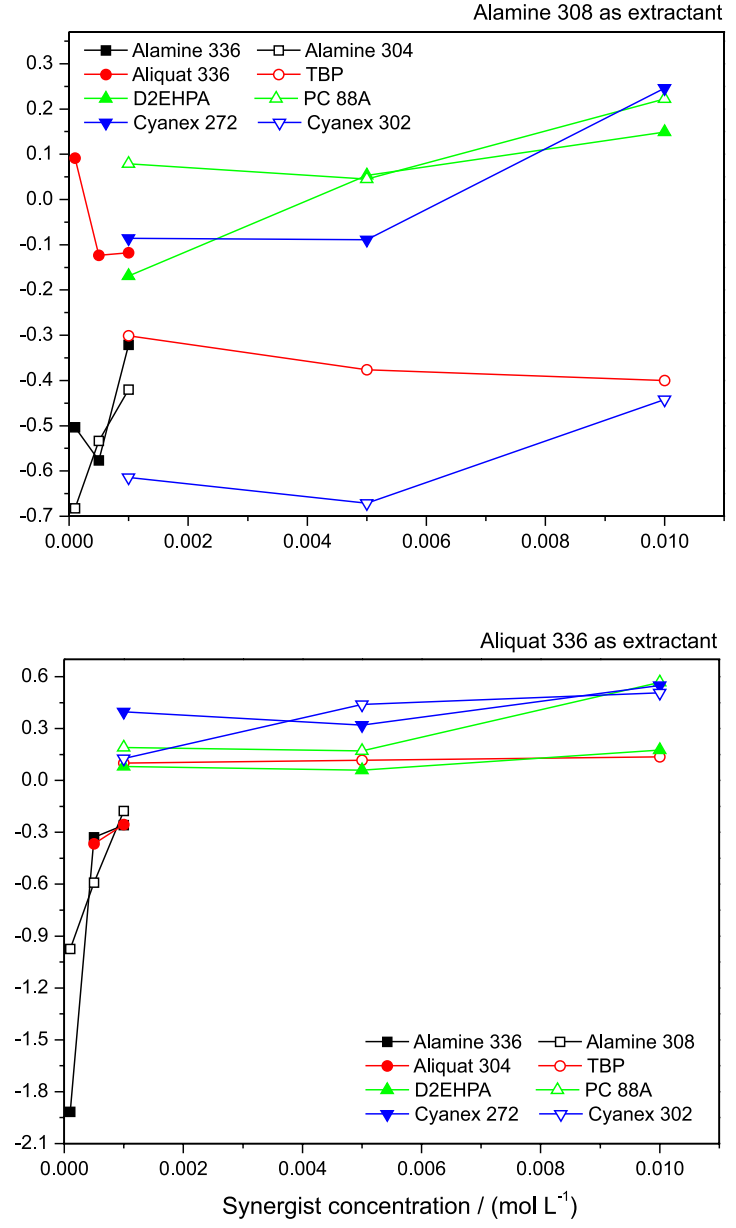

transferred into the organic phase in each contact was calculated by difference and the cumulative concentration of uranium in the organic phase after each stage of contact was determined. The plot of cumulative addition of $[\mathrm{U}(\mathrm{VI})]_{\text {org }}$ with Alamine 336 or Alamine 308 or Alamine 304 or Aliquat 336 vs. contact number is given in Figure 7. It is clear that most of the uranium existing in the aqueous phase was extracted into the organic phase up to $17^{\text {th }}$ stage for Alamine 336, $3^{\text {rd }}$ stage for Alamine 308, $10^{\text {th }}$ stage for Alamine 308 and $3^{\text {rd }}$ stage for Aliquat 336 . An analysis of loaded organic showed that it contained 449.02, 272.27, 58.4 and $173.8 \mathrm{mg} \mathrm{L}^{-1}$ of Alamine 336, Alamine 308, Alamine 304 and Aliquat 336, respectively. The loading capacity of the $\mathrm{U}(\mathrm{VI})$ to concern extractant followed the order: Alamine 336 > Alamine 308 > Aliquat 336 > Alamine 304.

\section{Stripping (back extraction) studies}

Uranium(IV) stripping from a loaded organic solvent system, $0.01 \mathrm{~mol} \mathrm{~L}^{-1}$ Alamine 336 containing $449.02 \mathrm{mg} \mathrm{L}^{-1}$, $0.01 \mathrm{~mol} \mathrm{~L}^{-1}$ Alamine 308 containing $272.27 \mathrm{mg} \mathrm{L}^{-1}$, $0.01 \mathrm{~mol} \mathrm{~L}^{-1}$ Alamine 304 containing $58.4 \mathrm{mg} \mathrm{L}^{-1}$ and 
$0.01 \mathrm{~mol} \mathrm{~L}^{-1}$ Aliquat 336 containing $173.8 \mathrm{mg} \mathrm{L}^{-1}$ were investigated using water and mineral acids $\left(5.0 \mathrm{~mol} \mathrm{~L}^{-1} \mathrm{HCl}\right.$, $\mathrm{H}_{2} \mathrm{SO}_{4}$ and $\mathrm{HNO}_{3)}$ as stripping reagents. The percentage stripping followed the order with amine based extractants to recover the $\mathrm{U}(\mathrm{VI})$ to back:

(i) Alamine 336: $\mathrm{HNO}_{3}>\mathrm{H}_{2} \mathrm{O}>\mathrm{H}_{2} \mathrm{SO}_{4}>\mathrm{HCl}$;

(ii) Alamine 308: $\mathrm{HNO}_{3}>\mathrm{H}_{2} \mathrm{O}>\mathrm{HCl}>\mathrm{H}_{2} \mathrm{SO}_{4}$;

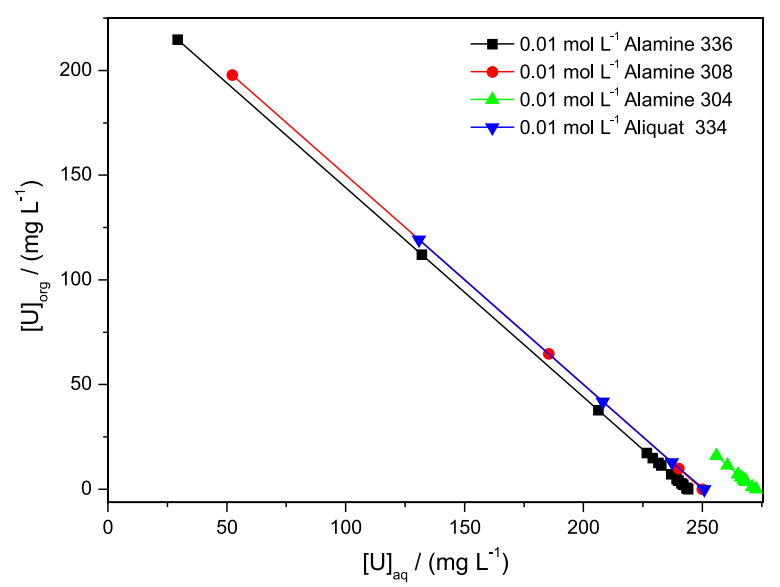

Figure 6. Uranium metal distribution to aqueous phase to organic phase at the time of the metal loading process.
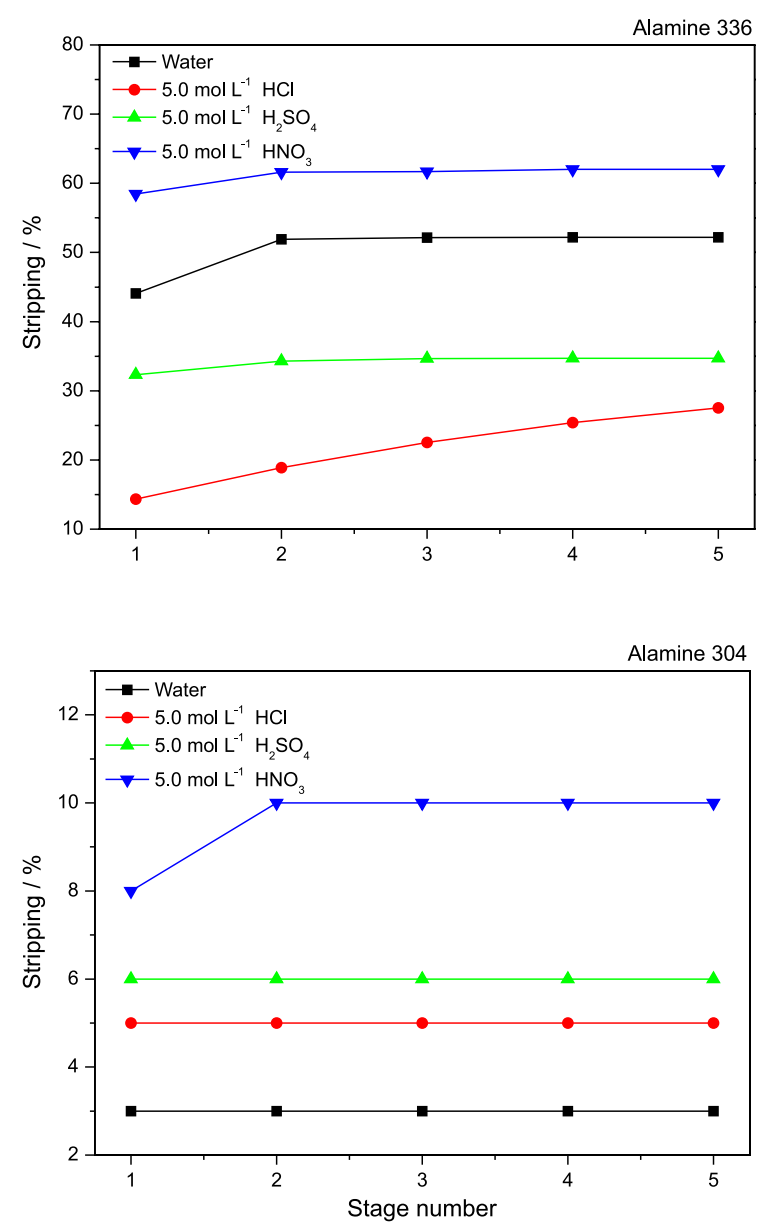

(iii) Alamine 304 and Aliquat 336: $\mathrm{HNO}_{3}>\mathrm{H}_{2} \mathrm{SO}_{4}>\mathrm{HCl}>$ $\mathrm{H}_{2} \mathrm{O}$.

The results clearly demonstrated that $\mathrm{HNO}_{3}$ was the best stripping reagent for uranium back extraction from the loaded organic, at the same time by environmental protection point of view, $\mathrm{H}_{2} \mathrm{O}$ was the best stripping reagent except in case of Aliquat 336 as extractant (Figure 8).

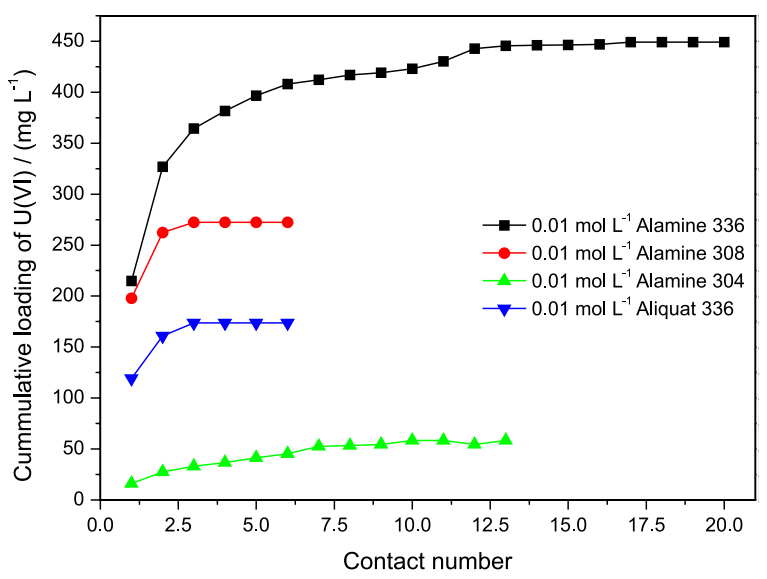

Figure 7. Loading capacities of amine based extractants for uranium extraction.
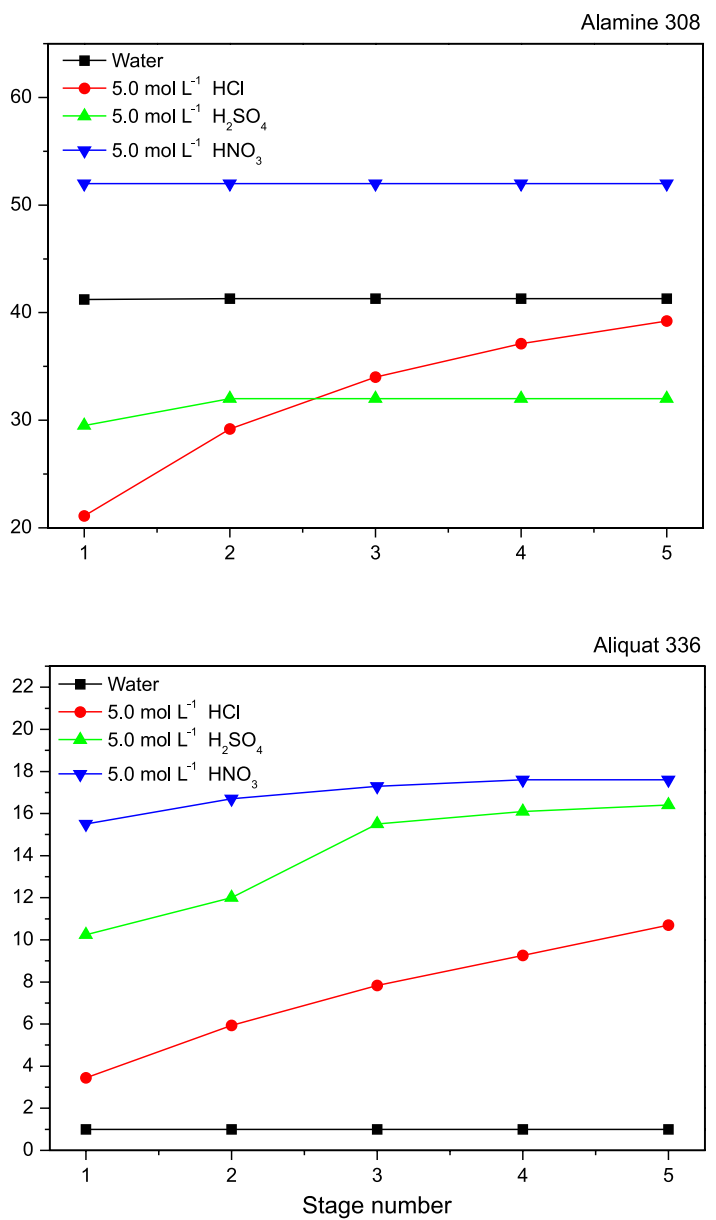

Figure 8. Stripping (back extraction) of the uranium from loaded organic phase by water and mineral acids. 

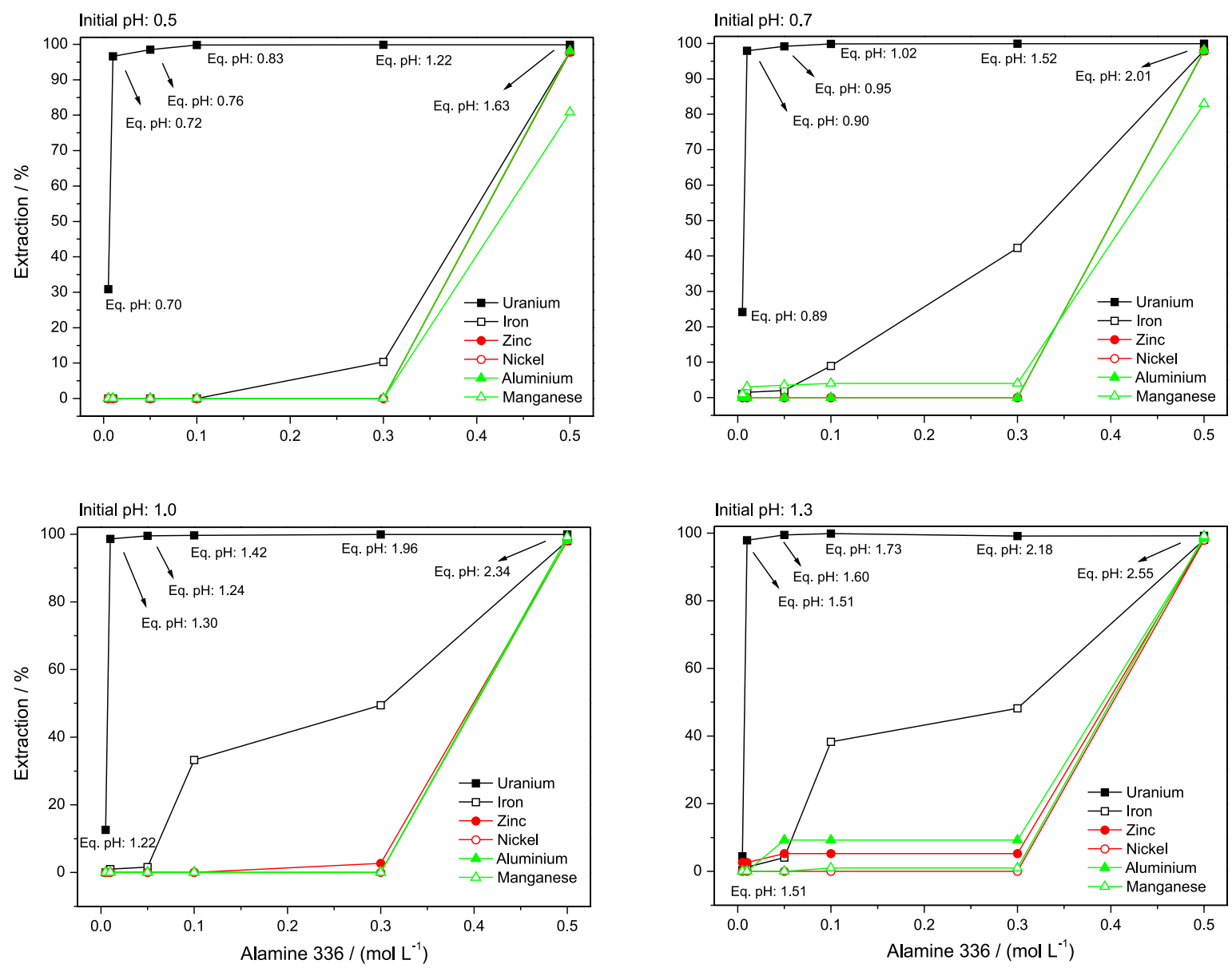

Figure 9. Recovery of the uranium from uranium ore leach liquors and separation of the other metals (iron, zinc, nickel, aluminum and manganese) by using Alamine 336 as extractant.

Recovery of the uranium from low grade ore leach liquors

Based on the above results, Alamine 336 was proved to be the best extractant for uranium extraction. The present scientific study applied to uranium extraction processing of the Korean domestic low grade ore leach liquors by using Alamine 336 as extractant. The leach liquor contained the following metals: $4.78 \mathrm{~g} \mathrm{~L}^{-1}$ of iron, $0.393 \mathrm{~g} \mathrm{~L}^{-1}$ of zinc, $0.112 \mathrm{~g} \mathrm{~L}^{-1}$ of nickel, $1.17 \mathrm{~g} \mathrm{~L}^{-1}$ of aluminum, $17.77 \mathrm{~g} \mathrm{~L}^{-1}$ of manganese and $0.133 \mathrm{~g} \mathrm{~L}^{-1}$ of uranium. The initial $\mathrm{pH}$ value varies from 0.5 to 1.3 , four sets of experiments were carried for uranium recovery and separation from other associated elements (Figure 9). The obtained results demonstrated that a pH value of 0.5 with $0.1 \mathrm{~mol} \mathrm{~L}^{-1}$ Alamine 336 achieved $99.83 \%$ of uranium extraction with clear separation from other associated elements, iron, zinc, nickel, aluminum and manganese (Figure 9a).

\section{Conclusions}

The present experimental investigations were developed for uranium extraction and separation of iron, zinc, nickel, aluminum and manganese from sulfate leach liquors of uranium low grade ore. Amine based extractants Alamine 336, Alamine 308, Alamine 304 and Aliquat 336 were proposed as promising reagents for the uranium extraction and recovery from other associate elements. The present experimental results concluded the following features:

(i) Extraction efficiency of all the four extractants followed the order: Alamine $336>$ Alamine $308>$ Alamine $304>$ Aliquat 336.

(ii) The synergic studies pointed that amine based extractants were not suitable for extraction efficiency improvement. In contrast, organophosphorus reagents were well suitable for extraction efficiency improvement through mixing with amines and order of the synergistic behavior was as follows: Aliquat $336>$ Alamine $336>$ Alamine $308>$ Alamine 304.

(iii) Loaded capacity of the amine based extractants followed the order: Alamine $336>$ Alamine $308>$ Aliquat $336>$ Alamine 304.

(iv) Back extraction of the metal from loaded organic phase was as follows: $\mathrm{HNO}_{3}>\mathrm{H}_{2} \mathrm{O}>\mathrm{H}_{2} \mathrm{SO}_{4}>\mathrm{HCl}$ for 
Alamine 336; $\mathrm{HNO}_{3}>\mathrm{H}_{2} \mathrm{O}>\mathrm{HCl}>\mathrm{H}_{2} \mathrm{SO}_{4}$ for Alamine 308; $\mathrm{HNO}_{3}>\mathrm{H}_{2} \mathrm{SO}_{4}>\mathrm{HCl}>\mathrm{H}_{2} \mathrm{O}$ for Alamine 304 and Aliquat 336

(v) The present scientific investigations concluded that, Alamine 336 was the best extractant for uranium extraction when compared with other amine based extractants in sulfate solutions, and finally, uranium low grade ore processing was successfully applied with $99.83 \%$ uranium recovery with zero other element (iron, zinc, nickel, aluminum and manganese) interferes.

\section{Acknowledgments}

This work was supported by the Energy Efficiency \& Resources (Physical and Chemical mineral dressing/ refining of low grade uranium ore) of the Korea Institute of Energy Technology Evaluation and Planning (KETEP) grant funded by the Korea Government Ministry of Knowledge Economy. Thanks are also for Cognis Company, USA for providing all amine based extractants as gift samples.

\section{References}

1. Nigond, L.; Musikas, C.; Cuillerdier, C.; Solvent Extr. Ion Exch. 1994, 12, 297.

2. Nair, G. M.; Prabhu, P. R.; Mahajan, G. R.; J. Radioanal. Nucl. Chem. 1994, 182, 393.

3. Nair, G. M.; Mahajan, G. R.; Prabhu, P. R.; J. Radioanal. Nucl. Chem. 1995, 191, 323.

4. Nakamura, T.; Miyake, C.; Solvent Extr. Ion Exch. 1995, 13, 253.

5. Preston, J. S.; Du Preez, A. C.; Solvent Extr. Ion Exch. 1995, 13, 391.

6. Ruikar, P. B.; Nagar, M. S.; Subramanian, M. S.; Gupta, K. K.; Varadarajan, N.; Singh, R. K.; J. Radioanal. Nucl. Chem. 1995, 196, 171.

7. Moore, F. L.; Anal. Chem. 1958, 30, 908.
8. Južnič, K.; Fedina, S.; Mikrochim. Acta 1974, 62, 39.

9. Goldenberg, J. F.; Abbruzzese, C.; Int. J. Miner. Process. 1983, $10,241$.

10. Lyle, S. J.; Tamizi, M. A.; Hydrometallurgy 1983, 11, 1.

11. Ito, K.; J. Radioanal. Nucl. Chem. 1993, 171, 371.

12. Behera, P.; Mishra, R.; Chakravortty, V.; J. Radioanal. Nucl. Chem. 1993, 173, 161.

13. Biswas, S.; Hareendran, K. N.; Singh, D. K.; Sharma, J. N.; Roy, S. B.; J. Radioanal. Nucl. Chem. 2010, 283, 665.

14. Gamare, J. S.; Chetty, K. V.; Mukerjee, S. K.; Kannan, S.; Anal. Sci. 2009, 25, 1167.

15. Takahashi, Y.; Hotokezaka, H.; Noda, K.; Nogami, M.; Ikeda, Y.; J. Nucl. Sci. Technol. 2009, 46, 787.

16. Lapka, J. L.; Paulenova, A.; Alyapyshev, My.; Babain, V. A.; Herbst, R. S.; Law, J. D.; Radiochim. Acta 2009, 97, 291.

17. Singh, S. K.; Dhami, P. S.; Tripathi, S. C.; Dakshinamoorthy, A.; Hydrometallurgy 2009, 95, 170.

18. Jha, R. K.; Gupta, K. K.; Kulkarni, P. G.; Gurba, P. B.; Janardan, P.; Changarani, R. D.; Dey, P. K.; Pathak, P. N.; Manchanda, V. K.; Desalination 2008, 232, 225.

19. Egorova, N. S.; Belova, V. V.; Voshkin, A. A.; Khol'Kin, A. I.; Pyartman, A. K.; Keskinov, V. A.; Theor. Found. Chem. Eng. 2008, 42, 708.

20. Kumar, J. R.; Lee, J. Y.; Kim, J. S.; Yoon, H. S.; J. Radioanal. Nucl. Chem. 2010, 285, 301.

21. Yakubu, N. A.; Dudeney, A. W. L.; Hydrometallurgy 1987, 18, 93.

22. Collet, S.; Chagnes, A.; Courtaud, B.; Thiry, J.; Cote, G.; J. Chem. Techol. Biotechnol. 2009, 84, 1331

23. Kumar, J. R.; Kim, J. S.; Lee, J. Y.; Yoon, H. S.; Sep. Purif. Rev. 2011, 40, 77.

24. Lee, J. Y..; Kumar, J. R.; Kim, J. S.; Park, H. K.; Yoon, H. S.; J. Hazard. Mater. 2009, 168, 424.

25. Devi, N. B.; Nathsarma, K. C.; Chakravortty, V.; Hydrometallurgy 1994, $34,331$.

Submitted: January 9, 2012

Published online: June 14, 2012 